\title{
Standardisation in European Higher Education. The Bologna Process and Hungary
}

\author{
Zoltan Zakota \\ Partium Christian University, Romania
}

\begin{abstract}
When speaking about innovation in education and teaching, people usually refer to changes fostered by innovation in technology for the purpose of learning, teaching, and curriculum development. The reason why this happens is obvious: technical / technological changes do happen fast and their effects are more spectacular than the effects induced by the slower, but longer lasting institutional innovation. One of the most important such innovation that occurred in Europe, in the last decades, is the Bologna Process. Its relevance is given, beneath encouraging mobility, mainly by opening the possibility of standardization and commensurability for the European national Higher Education systems. European nation-states do consider education one of the main territories of national sovereignty, sometimes even by raising artificial barriers in the way of rapprochement. In my paper, I intend to present the main advantages of the Bologna Process, the art it gained ground in Europe and the main dangers lurking on it, especially nationalist populism. As an illustration, I will use the case of Hungary, one of the member-states with the most ambiguous attitudes towards the EU and its integration process.
\end{abstract}

Keywords: Higher Education, Standardization, Flexibility, Bologna Process, Hungary JEL classification: I23

\section{Introduction}

In a broad sense, standardization is an activity consisting of the development, issuing and application of standards, which provides general and repeatable solutions to existing or expected problems with the aim of making the rendering effect the most favourable in the given conditions. In the context of technology and industry, standardization represents a process in which a technical standard is developed by the appropriate organizations. From an economic point of view, it is also conceivable that standardization is a means of optimizing the use of rare or diminishing resources. Standardization connotes cooperation with each other on the market; in a beneficial way to all parties, without violating competition.

In the field of social action, standardization means the practice of introducing different rational rules, in order to facilitate and make more efficient transactions between people. In standardizing social activities, formalization, that is, the binding of unregulated practices, is being applied to the respective fields. These fields do cover, practically, the complete social spectrum, containing justice, healthcare, policing or education. Standardization is also present in major social changes, including different processes, such as modernization, bureaucratization, homogenization and centralization, or regionalization and decentralization. 
Standards can exist in a de facto way, which means that they are kept because they assure some benefits, or in a de jure or obligatory way, that is, they are kept because of some legally binding treaties and documents. We can differentiate also open and protected standards, as well as world and national standards. National standards are adopted by the respective national standardization institutions, which keep and respect them as prerequisites for entering certain markets or to cooperation within groups.

In order to be able to do a pertinent analysis we need a modern, comprehensive definition of standardization. The one that fits best to our goal is the definition adopted by the International Organization for Standardization, according to which: "An International Standard provides rules, guidelines or characteristics for activities or for their results, aimed at achieving the optimum degree of order in a given context. It can take many forms. Apart from product standards, other examples include: test methods, codes of practice, guideline standards and management systems standards" (International Organization for Standardization, n.d.).

\section{Methodology}

In my study, I started from the definition of standardization, by taking into consideration not only its applications in the realm of education, in general, but especially those in the field of higher education. One of the prevalent viewpoints of my analysis was that of the Bologna Process, as one of the most important means of standardization in education, esp. in the European Union. I based my study and, of course, my conclusions mostly on the events of post-adherence Hungary, which were, against all critics, a considerable success. On the other hand, this period contained also several step-backs in this process. Of significant importance were also my informal discussions with persons in key positions from the fields of administration, politics, culture and education, especially higher education. I also tried not to leave out of consideration the cultural and historical specificities of Hungary, which still are sources of several wounds, offences and prejudices.

\section{Results}

\section{Standardization in Higher Education}

As Ursula Kelly, lain McNicoll and James White states in their report "[...] evidence confirms that higher education (defined as the universities together with the expenditure of their staff, international students and international visitors) is a substantial industry, with a significant impact on the national economy. It also reveals that higher education is particularly effective in generating GDP per capita, compared to several other sectors of the economy" (Kelly et al., 2009, p.25).

Although debates over the correlations between education investments and economic growth are still going on, it is in undeniable, that higher education is capable to generate considerable incomes, at least in Europe and North-America. It is hard not to notice how this income generating capacity of higher education appeared and went high in the Central and Eastern European countries after the fall of communism and the rise of private universities.

While functioning, universities generate output and employment, but in addition to all these, their expenditure generates also additional output and employment in other sectors of the economy through secondary or, so-called, 'knock-on' multiplier effects. On one hand, these can be indirect effects: by purchasing goods and services from other sectors, universities support their own activity, thereby stimulating those industries. On the other hand, there are induced effects: universities pay wages and salaries to their own employees, who in turn spend this income on 
consumer goods and services, creating wage income for employees in other sectors.

As it usually happens, sectorial growth and internationalization induces the need for standardization. Education and especially higher education, as a noncompulsory part of it, are no exceptions. Standards contain a lot of codified knowledge, so they can act as essential instruments in the dissemination of best practice and means of technology transfer. Measures for voluntarily apply them are more likely to benefit business. In fact, there are costs of implementation, but these will be surpassed by the benefits, once an agreed benchmark is established through the standard and if the market adjusts itself. As stated in Henry (2010, p.122), "the benefits of implementing a standard for business include: a) Enhanced market share due to market demand for standards compliance, b) Preferential treatment by government, c) Simplifying business-to-business trade, d) Improved production efficiency, and e) Reduced hence inventory costs as a result of the need to hold fewer varieties."

One of the most important roles of standards is supporting innovation. According to Swann (2007), there are several mechanisms at work, such as:

1. standards support the division of labour, and by that certain types of innovation activity;

2. open standards can help to open up markets and allow new entrants, which can be a powerful force for innovation;

3. the existence of generally accepted measurement standards allows proving that innovative products do indeed have superior performance;

4. standards help deriving the greatest value from networks;

5. open standards allow innovative entrants to take advantage of network effects, and benefit from compatibility with core technologies.

Debates continue among specialists about standardization and its effects. It is considered both useful and harmful, having advantages as well as disadvantages. The question is put really sharply in the case of education. The debates are going on especially about the nature and degree of standardization. In the following table I try to synthesize the different opinions:

\section{Standardization and the Bologna Process}

Since 1999 the Bologna Declaration and Process have radically transformed the image of European higher education. Due to the many achievements and the established common attributes, despite all its shortcomings, we now can rightly speak about a European Higher Education Area (EHEA). There have been many achievements in these almost twenty years, involving several top educational issues, like quality assurance or recognition of diplomas. The process aims at harmonizing the higher educational systems in Europe; ideas of comparability, mobility, transparency, harmonization, flexibility, shared European values and diversity are put forward as means to create a European educational space (Fejes, 2008).

Although the proposed harmonization process in all the mentioned fields had to imply, almost in a mandatory way, the appearance of de facto standards, the notion of standardization appears also explicitly when talking about the Standards and Guidelines for Quality Assurance in the European Higher Education Area (ESG). These standards "were adopted by the Ministers responsible for higher education in 2005 following a proposal prepared by the European Association for Quality Assurance in Higher Education (ENQA) in cooperation with the European Students' Union (ESU), the European Association of Institutions in Higher Education (EURASHE) and the European University Association (EUA)" (ENQA et al. 2015, p.5). 


\section{Table 1}

\section{Advantages and Disadvantages of Standardization in Education}

\begin{tabular}{|c|c|}
\hline $\begin{array}{l}\text { Standardization } \\
\text { Issue }\end{array}$ & Advantages \\
\hline $\begin{array}{l}\text { level, Pace, } \\
\text { and Path of } \\
\text { learning }\end{array}$ & $\begin{array}{l}\text { - Ease of implementation at scale. } \\
\text { - Meets expectations of educators, community, } \\
\text { and politicians. } \\
\text { - Already implemented at scale. } \\
\text { - Reduces risks associated with change. }\end{array}$ \\
\hline Curriculum & $\begin{array}{l}\text { - Supports some level of equity. } \\
\text { - Reduces harm that can be done by poor } \\
\text { teachers. } \\
\text { - Supports continuation of status quo. } \\
\text { - Reduces risks associated with change. }\end{array}$ \\
\hline Assessments & $\begin{array}{l}\text { - Can be a useful tool for comparing } \\
\text { achievements of large student groups and } \\
\text { identifying systemic disparities. } \\
\text { - Can provide insight in student achievement as } \\
\text { compared with other schools. } \\
\text { - It is possible to provide feedback loops in order } \\
\text { to improve schooling. }\end{array}$ \\
\hline
\end{tabular}

\section{Discadvantages}

- Inefficient for any given student

learning.

- Contributes to disengagement

among students.

- Severely limits the opportunities for students to leam.

- Enforces a one-size-fits all curriculum

- De-professionalizes teaching by

marginalizing the professional

judgment, experience, and skill.

- Tends to shift professional practice

towards content coverage and away from deep understanding.

- Are expensive to administer at scale

and so are generally discarded in

favour of multiple-chaice tests.

- Are leading to the belief that

student growth is reflected by their

performance on some specific tests of knowledge.

- Biases schools towards focusing on

test success at the cost of other learning

that may better serve students in the

long run.

- There is a relative paucity of qualitystandardized tests and immaturity of scalable standardized testing.

- One often meets inappropriate use

of data with limited validity and scope.

- Schools are biased against spending

time and energy on teaching and

learning beyond standardized "rote performance" level.

- Standardized expectations are likely

"process" of teaching and learning to the

"outcomes".

- It makes possible to innovate at the level of personalization, in the "how" of teaching and learning.

- Strongly supports market-driven innovations for teaching and learning by consolidating the market and making it viable for innovative new products to reach a wide audience.

Data Formats - Enable sharing of data between educational

and applications.

Interoperability - Provide a complete and coherent set of data in order to personalize students' learning.

- Provide anonymized data back to educational software developers to help them rapidly improve the quality of their offerings.

- Provide anonymized and aggregated data to scholars and researchers to help improve education science

- Well-structured feedback loops including student data could drive innovations and improve learning on internet time.

- Making data available to researchers opens doors for understanding learning that becomes qualitatively different from the kinds of research

to outstrip our ability to assess outcomes against them

- Can create opportunities for exploitation, through the deliberate or accidental revelation or commercial uses of private student information.

- Students may come to be defined (and therefore limited) by the necessarily narrow view created by the metrics and data chosen to be stored in standardized formats.

- Dangers of putting student data in the hands of commercial (or even scholarly) entities are unacceptable until we standardize mechanisms for ensuring student privacy. available prior to the advent of big dato.

\begin{tabular}{lll}
\hline $\begin{array}{l}\text { Level of Digital } \\
\text { Access }\end{array}$ & - Is a necessary (though not sufficient) step & There are significant costs to \\
& providing access for all students. \\
& There are even higher costs \\
& associated with the changes in culture \\
and practice required to take & advantage of aninfrastructure that \\
& provides $24 / 7$ digital access for all \\
& students.
\end{tabular}

Source: Bjerede (2013) 
The ESG are not mandatory norms for the implementation and / or application of quality prescriptions. Rather, they provide "guidance for successful quality provision and learning environments in higher education", including qualifications frameworks, the European Credit Transfer and Accumulation System (ECTS) and diploma supplement (ENQA et al. 2015, p.5).

As stated in ENQA et al., (2015, p.7), the ESG purposes and principles are, as follows:

- "They set a common framework for quality assurance systems for learning and teaching at European, national and institutional level;

- They enable the assurance and improvement of quality of higher education in the European higher education area;

- They support mutual trust, thus facilitating recognition and mobility within and across national borders;

- They provide information on quality assurance in the EHEA".

\section{The Bologna Process and the Hungarian Higher Education}

In 1999 Hungary has also signed the Bologna Declaration, but the current government convictions of what was better to Hungary at that moment were of pretty precarious nature. The signature of the declaration of the accession process was seen as an act of no real importance, although the government considered opting out of it not recommended.

Because of the Bologna Process, in 2004 in Hungary has begun a gradual transition from the Soviet model of higher education to the three-cycle system, with the two continuing to exist in parallel for several years. The sudden haste was not good for the reform because it left not enough time for a thorough preparation of the process, for preventing errors and mistakes, or even to try a gradual introduction. In addition, the beginning of the reform coincided with the expansion of higher education in Hungary, causing several problems. The lack of strategy and the shortterm approach was noticeable especially by the introduction of the two-staged academic system. In many cases, the bachelor-level studies were started without a real planning of their structure and content, by simply "re-tailoring" the previous fouror five-year long studies. Due to the three year-long transition period, the introduction of the master-level studies proceeded in a much smoother way.

The new educational system had to prepare students for two, almost incompatible, alternatives. On one hand, when having finished their bachelor and / or master studies they had to be ready to enter the labour market. On the other hand, at a certain level of excellence, they had to be able to continue their studies at a higher level. This ambiguity has lowered the confidence in the new system inside the academic sphere, turning many of its representatives against it.

The implementation of the ECTS, as one of the main means of encouraging student mobility also created, at least in its first years, uncertainty and discomfort among many higher education representatives. One shall not forget, that mobility, in general, and especially student mobility was practically inexistent during communism. Even attending courses of another faculty or university was very difficult. So, mobility and credit recognition, two main goals of the Bologna Process and two main means of standardization of European higher education, were treated with relatively high suspicion, at least in the beginning.

Due to its highly centralised character, Hungarian education, in general, and higher education, in particular, always constituted one of the mostly beloved "playgrounds" of politics. Assuming the risk of over-simplifying things, we can notice the existence of two main trends in Hungarian higher education politics. On one 
side, there were the socialist and liberal governments, which supported a so-called "leftist", more or less liberal, decentralizing, pro-Europe politics, supporting a relative autonomy of the academic life. On the other side, there are the so-called "rightist" or "conservative" forces, which do support centralization, stressing national values instead of general European ones, being interested, in some degree, in dismantling the structures based on the Bologna Process.

A good illustration of the immixing of politics in higher education is the way doctoral studies were transforming in the last almost three decades. As we know, higher education is an inflexible realm, so after the fall of communism Hungary kept its Prussian-rooted soviet system. Changes were made only when the country adopted the Bologna Process and joined the Union: the three years-long doctoral study schemes were adopted. After the conservative-nationalist regime strengthened its position, it radically changed educational politics and as a part of it the structure of doctoral studies. Now they are more similar to the old system, lingering for four years and containing a complex examination.

\section{Conclusion}

After World War II education, including higher education underwent a process of modernization, becoming a proper industry. Universities shifted from a Humboldtian model to a market-oriented one. As they become more and more accessible to the masses and go through a process of globalization, as the level and range of student and staff mobility raises, the need for standardization in higher education raises too. One of the most efficient means to attain this is the Bologna Process, adopted by almost half a hundred countries, especially European ones, and among them Hungary.

However, there is a basic conflict between the goals of the process, on adopting standards while preserving academic autonomy and national specificities. As stated in (ENQA et al., 2015, p. 8): "These purposes provide a framework within which the ESG may be used and implemented in different ways by different institutions, agencies and countries. The EHEA is characterised by its diversity of political systems, higher education systems, socio-cultural and educational traditions, languages, aspirations and expectations. This makes a single monolithic approach to quality and quality assurance in higher education inappropriate. Broad acceptance of all standards is a precondition for creating common understanding of quality assurance in Europe. For these reasons, the ESG need to be at a reasonably generic level in order to ensure that they are applicable to all forms of provision."

On what a degree this conflict can affect higher education and in what way it can be exploited by different political groups we can see it in the case of postadherence Hungary. Its case illustrates well the effects of unpreparedness for changes, low adaptability and excessive centralization and state control on higher education. 


\section{References}

1. Bjerede, M. (2013), "Getting Smart", available at: http://www.gettingsmart.com/2013/04/education-standardization-essential-orharmful/ (20 August 2018)

2. ENQA (2015), "ENQA European Association for Quality Assurance in Higher Education", available at:

http://www.enqa.eu/wp-content/uploads/2015/11/ESG 2015.pdf (21 August 2018)

3. Fejes, A. (2008), "European citizens under construction: The Bologna process analysed from a governmentality perspective", Educational Philosophy and Theory, Vol. 40, No. 4 , pp. 515-530.

4. Henry, J. (2010), "Economic Impacts - Micro Perspective", in Choi, D., Kang. B., Kim, T. (Eds.), Standardization: Fundamentals, Impact and Business Strategy, Seoul, Asia Pacific Economic Cooperation Secretariat.

5. International Organization for Standardization (n.d.), "ISO International Organization for Standardization", available at: https://www.iso.org/deliverables-all.html (19 August 2018)

6. Kelly, U., McNicoll, I., White, J., (2009), "The Impact of Universities on the UK Economy, Fourth Report", available at:

https://www.universitiesuk.ac.uk/policy-and-analysis/reports/Documents/2014/theimpact-of-universities-on-the-uk-economy.pdf (20 August 2009)

7. Swann, G. M. P. (2007), "Standards are Central to Wealth Creation", Wissenschaftsmanagement, Vol. 2, pp. 26-27. 


\section{About the author}

Zoltan Zakota is lecturer at the Partium Christian University, in Oradea, Romania. He is a co-founder of the departments of Management and that of Finances. At present, he is lecturing computer science, application of informatics in economics and society, decision theory. His main fields of interest are information and knowledgebased society, the effects of ICT on society, economics and education. Actually, he is involved in two main projects: one of them dealing with the European higher education and the other concerning the effects of the Romanian-Hungarian transfrontier cooperation on regional development. The author can be contacted at zzakota@gmail.com. 